\title{
Effect of addition JORPHOS to Self-Compacting Concrete for Chloride Penetration
}

\author{
Mahmoud B. Alhasanat ${ }^{1}$, Arabi N. S. Al Qadi ${ }^{1}$, Loai A. Al Tarabulsi ${ }^{1}$, \& Omar A. Al khashman ${ }^{2}$ \\ ${ }^{1}$ Civil Engineering Department, College of Engineering, Al-Hussein Bin Talal University, Ma'an, Jordan \\ ${ }^{2}$ Environmental Engineering Department, College of Engineering, Al Hussien Bin Talal University, Ma'an, Jordan \\ Correspondence: MahmoudAlhasanat, Civil Engineering Department, College of Engineering, Al-Hussein Bin \\ Talal University, Ma'an, Jordan. E-mail: 20petra07@gmail.com
}

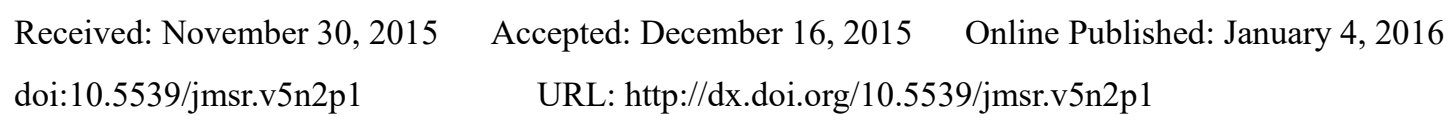

\begin{abstract}
Reinforced concrete structures are exposed to harsh environments, yet they are often expected to last with little or no repair or maintenance for long periods of time (often 100 years or more). For this reason, a durable structure needs to be produced. In addition, bridge reinforced concrete suffering from attacks of chloride penetration that cause corrosion of the steel in the reinforcement concrete that leads to reduction in strength and serviceability cracking, which cause further repair and rehabilitation for the structure and greater maintenance and repair costs. This research focuses on self-compacting concrete with Jordanian Phosphate (JORPHOS) as a filler. The permeability for different percentages of JORPHOS were tested by using Rapid Chloride Permeability Test (RCPT). It was concluded that the addition of different percentages of JORPHOS minimizes chloride penetration in concrete.
\end{abstract}

Keywords: permeability, corrosion, JORPHOS, durability, chloride

\section{Introduction}

Concrete is the ideal environment for steel because of its highly alkalinity ( $\mathrm{pH}$ 12.5-13.8) pore solution contained in the cement paste component, which passivates the steel. However, concrete contains cracks and pores; and is not impervious to the ingress of chloride salts that break down the passive layer of the reinforcing steel (i.e. rebar). Considerable work has been done to examine chloride ingress through the concrete pore network (Sandberg et al., 1998; Dhir \& Jones et al., 1996; Jensen et al., 1999; Gjorv \& Vennesland, 1979) and its effect on the corrosion of rebar (Mohammed et al., 2004; Hope \& Ip, 1987; Beaudoin et al., 2000). It is clear that the quality and depth of the concrete cover is of major importance to determine the durability of the structure (Jaegermann, 1990).

Chloride is considered the major cause of the corrosion of steel reinforcement in the concrete structures. Concrete provides physical and chemical protection to the reinforcing steel from penetrating chlorides, which may cause steel depassivation that leads to increased risk of steel corrosion. Chloride resistance depends on the permeability of concrete and the thickness of the cover to the reinforcement. Additionally, the integrity of the concrete cover under service load in terms of cracking and crack width influences resistance to penetrating chlorides. Corrosion of steel reinforcement is an electrochemical process. Hence, the electrochemical properties of concrete, such as resistivity, are important inherent properties that affect the corrosion rate of reinforcing steel (Guirguis et al., 1989).

Metha (1988) reconfirmed from a review of case studies that it is the permeability of concrete, rather than its chemistry that is the key to overall durability. The causes of high permeability are not limited to poor concrete proportion but poor concreting practices, such as incomplete mixing, inadequate consolidation, curing after placement, insufficient cover to reinforcing steel, and badly constructed joints. In service, concrete may exhibit various forms of cracking for reasons such as settlement, premature loading, overloads, and repeated impact. The control of concrete cracking in service through proper mix proportioning and concreting practice is as important as the control of concrete permeability.

Steel reinforcement embedded in concrete is inherently protected against corrosion by passivation of the steel surface due to the high alkalinity of the concrete. When a sufficient amount of chlorides reach the steel reinforcement, then it permeates the passivating layer and increases the risk of corrosion. The resistivity of concrete can also be reduced, which affects the corrosion rate of the steel. 
For use in prestressed or reinforced concrete structures, the chloride concentrations in mixing water, cements, admixtures, and aggregates are carefully controlled; and the maximum allowable concentrations are given by the building standards (AS 1379). According to this standard the chloride concentration must not exceed $0.8 \mathrm{~kg} / \mathrm{m} 3$ of the fresh concrete.

However, in most cases, good amount of chloride in concrete comes from external sources. The chloride penetration into the concrete occurs by different transport mechanisms that depend on exposure conditions. There are significant amounts of chloride in seawater but chlorides are more limited in groundwater and soil. In many countries, de-icing salts, which are used to combat the build-up of snow and ice on transport infrastructures, are the greatest sources of chlorides. In seawater, chlorides usually pose a greater threat to steel in concrete than sulfates do to concrete because calcium sulphoaluminate or ettringite (the expansive reaction product of sulfate and tricalcium aluminate in the cement) is more soluble in the presence of chloride; hence, it does not cause adisruptive expansion. Portland cement reacts with sodium chloride to form chloroaluminates or Friedel's salt thatimmobilizesthe chloride and reducesthe free chloride ions available to depassivate the steel. The results of a 34-year long-term exposure of plain and reinforced concrete beams in a tidal seawater exposure in Los Angeles Harbor in California in 1959 and 1961 (Stark \& David, 1995), found that all plain concrete mixtures (stored at approximately mean tide) display excellent resistance to seawater attack, regardless of cement composition, water-cement ratio, cement content, the use of SCM, and method of curing as well as freezing and thawing do not occur. However, severe cracking due to corrosion of embedded reinforcing steel developed in some beams stored above high tide, while only minor or no cracking developed in companion beams stored in seawater near mean tide levels. The most severe corrosion-induced cracking occurred in concrete with the highest w/c of 0.49 and least cover of $25 \mathrm{~mm}$. The relatively greater degree of steel corrosion in beams stored above high tide is attributed to the greater availability of oxygen at the reinforcing steel surface. Corrosion-related distress was found to be sensitive to concrete cover and water-cement ratio. Prestressed steel appeared to be no more vulnerable to galvanic corrosion than ordinary deformed reinforcing steel bars. The nickel and painted-on epoxy coatings appeared to provide little (if any) additional protection against corrosion (Concrete \& Australia, 2009).

\section{Method}

In this section the number of methods that were applied such as the volume method for determining the mix ratios are elucidated. The test conducted was the Rapid Chloride Permeability Test (RCPT) to determine the charges passing the core samples having different JORPHOS ratios.

\subsection{Materials Used}

Portland Cement: Ordinary Portland Cement (OPC) conforming to ASTM C150-85A (2006) as available in the local market was used in the investigation. The cement used has a specific gravity of $3.15 \mathrm{~g} / \mathrm{cm}^{3}$ and Blaine's fineness (Blaine) of $4500 \mathrm{~cm}^{2} \mathrm{gm}^{-1}$ (Table1).

Jordanian Phosphate: The specific gravity is 2.8 done according to ASTM-C188, while chemical composition of JORPHOS (Table 1) as follows.

Table 1. Chemical composition of JORPHOS and Cement

\begin{tabular}{lcc}
\hline Type & JORPHOS (\%) & Cement (\%) \\
\hline Tri Calcium Phosphate (TCP) & 58.44 & - \\
Acid Insoluble Resolution (cilia Air) & 11.64 & - \\
Loss of Ignition (LOI) & 9.41 .43 \\
$\mathrm{CO} 2$ & 7.74 & - \\
$\mathrm{CaO}$ & 46.27 & 63.21 \\
$\mathrm{SiO} 2$ & - & 19.6 \\
$\mathrm{MgO}$ & 0.49 & 3.15 \\
$\mathrm{Fe} 2 \mathrm{O} 3$ & 0.37 & 3.26 \\
$\mathrm{Cl}$ & 0.142 & - \\
$\mathrm{A} 12 \mathrm{O} 3$ & 0.86 & 5.32 \\
$\mathrm{SO} 3$ & 1.5 & 2.89 \\
$\mathrm{Na} 2 \mathrm{O} 3$ & 0.68 & 0.57 \\
$\mathrm{~K} 2 \mathrm{O}$ & 0.075 & 0.6 \\
Organic Matter & 0.18 & - \\
\hline
\end{tabular}


JORPHOS: JORPHOS was sieved using sieve \#200.

Potable Tap Water: Water conforming to BS3148 (1981) was used for mixing and curing.

Crushed Aggregate: Crushed angular limestone material of $20 \mathrm{~mm}$ nominal size from a local source was used as course and medium aggregate, while fine aggregate crashed silica sand with a combined of aggregate ( $28 \%$ coarse aggregate, $38 \%$ medium aggregate, and 34\% fine aggregate) all of these aggregate were of oven dry weight. Figure1 shows the sieving analysis according to ASTM C136. Specific gravity for combined aggregate was 2.534 and the absorption value was $1.751 \%$ conforming to ASTM C 33-86, (2006) (See Figure 1).

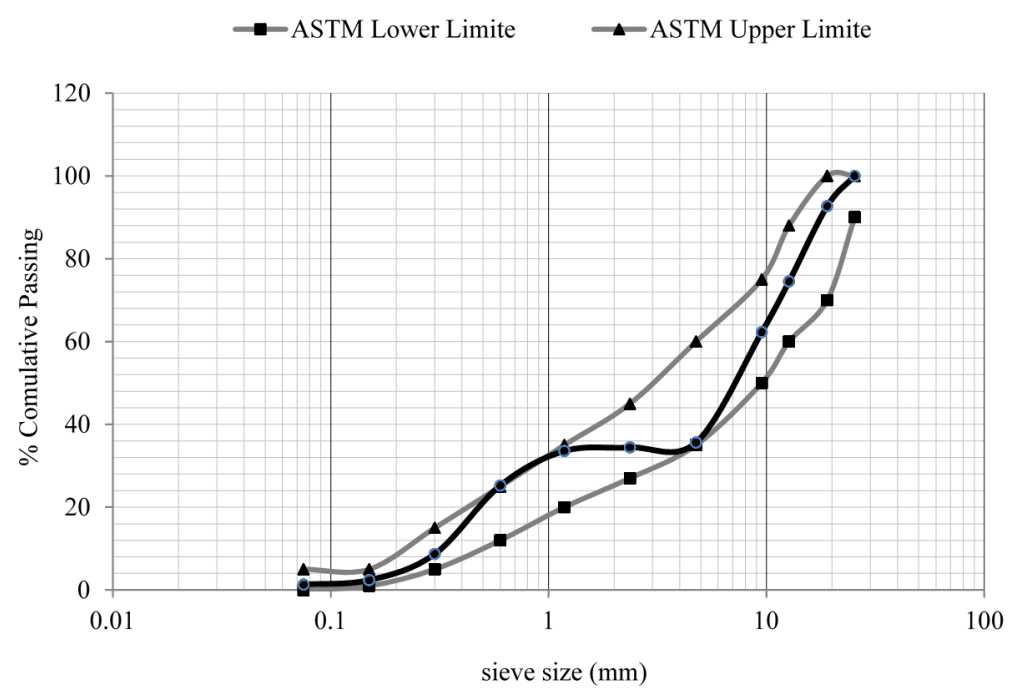

Figure 1. Sieving analysis of combined coarse, medium, and fine aggregate

\subsection{The Mixture Design}

The control mixture contains only the base components for any mixture without any additives, which are cement, water, and aggregate (Figure 2a). It will be the reference for all other mixtures that contain JORPHOS which is the replacement for the cement (Figure 2b). To achieve a high performance concrete depends on the European Guidelines by weight or volume of components for the related mixtures.

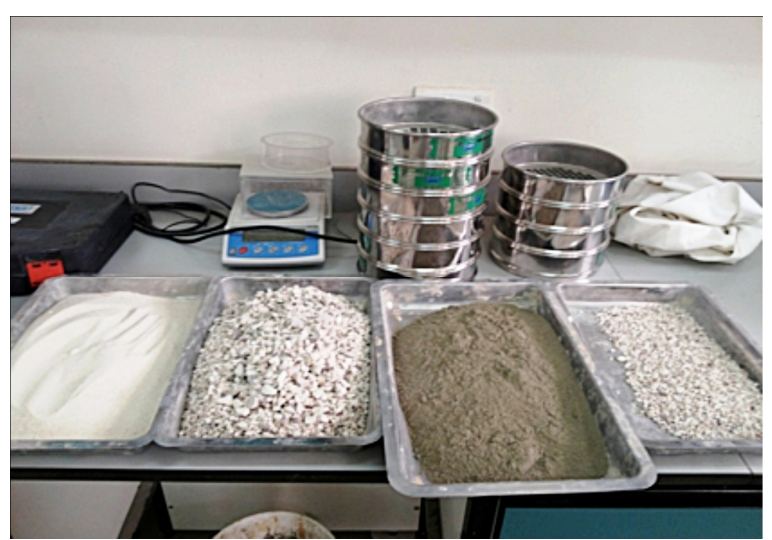

a. The materials after proper preparation (sieving, weighing)

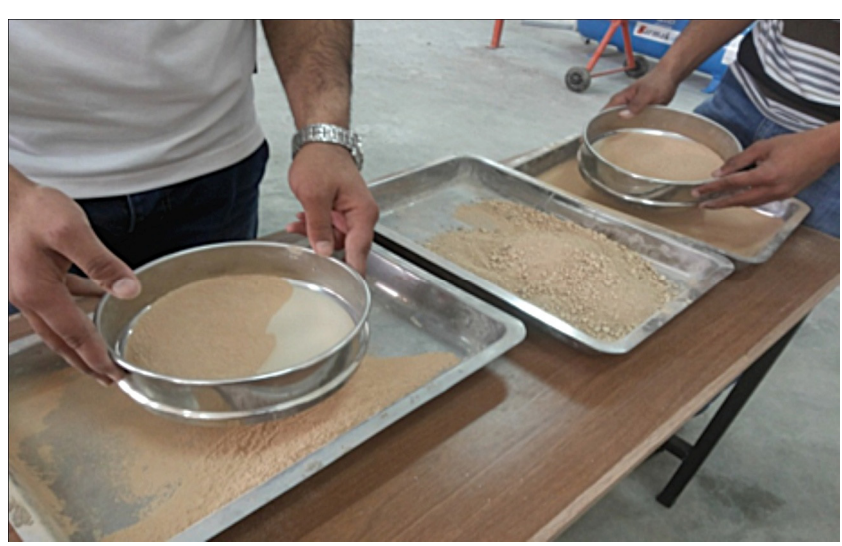

b. the JORPHOS passed through sieve \#200

Figure 2. The mixture components

The mix proportions that were used in the investigation and presented in Table 2 along with the response. All concrete mixes were prepared manually. 
Table 2. Mix proportions of SCC with different percentages of JORHPOS

\begin{tabular}{llllllllc}
\hline Mix No. & $\mathrm{C}(\mathrm{kg})$ & $\mathrm{W}(\mathrm{kg})$ & $\mathrm{CA}(\mathrm{kg})$ & $\mathrm{FA}(\mathrm{kg})$ & $\begin{array}{l}\text { Sand } \\
(\mathrm{kg})\end{array}$ & $\mathrm{W} / \mathrm{P}$ & $\begin{array}{l}\text { JORHPOS } \\
\text { mass } \%\end{array}$ & $\begin{array}{c}\text { JORHPOS. } \\
\text { Weight(kg) }\end{array}$ \\
\hline PC control & 1.15395 & 0.426 & 0.5321 & 2.327 & 1.933 & 0.37 & $0 \%$ & 0 \\
MJ4 & 1.10779 & 0.4337 & 1.32759 & 1.8 & 1.6 & 0.38 & $4 \%$ & 0.041 \\
MJ8 & 1.06 & 0.4519 & 1.315 & 1.785 & 1.59 & 0.40 & $8 \%$ & 0.082 \\
MJ12 & 1.015 & 0.47 & 1.303 & 1.77 & 1.58 & 0.41 & $12 \%$ & 0.123 \\
\hline
\end{tabular}

\subsection{Test Method}

The test consists of measuring the amount of electrical current passed through $50 \mathrm{~mm}$ thick slices of $100 \mathrm{~mm}$ diameter cylinders during a $6 \mathrm{~h}$ period. A 60 volt DC is maintained across the ends of the specimen, one of which is sink in a sodium hydroxide solution and the other in a sodium chloride solution.

\subsection{Test Specimens}

The cylinders cast in the laboratory were prepared according to C 192. Specimen mounting (rubber gasket alternative): Place a 4in. outside diameter by 3 in. inside diameter by $1 / 4$ in. $(100 \mathrm{~mm}$ outside diameter by $75 \mathrm{~mm}$ inside diameter by $6 \mathrm{~mm}$ ) circular vulcanized rubber gasket in each half of the test cell are placed. The Specimen inserted and the two halves of the test cell are together clamped to seal. The side of the cell containing the top surface of the specimen is filled with $3.0 \% \mathrm{NaCl}$. This side of the cell was connecting to the negative terminal of the electrical current. The other side of the cell was connecting to the positive terminal of the electrical current if filled with the $0.3 \mathrm{M} \mathrm{NaOH}$ solution.

The electrical current $60.0 \mathrm{~V}$ connected on, and initial current reading was recorded. Temperatures of the specimen, applied voltage cell, and solutions was around $23^{\circ} \mathrm{C}$. During the test, the air temperature around the specimens was maintained in the range of $68-77^{\circ} \mathrm{F}\left(20-25^{\circ} \mathrm{C}\right)$. The current was recorded at every $30 \mathrm{~min}$. Each half of the test cell was filled with the appropriate solution for the entire period of the test. Terminate test was after $6 \mathrm{~h}$.

\section{Results}

The main test of this study is the rapid chloride permeability test whose name is self-explanatory and determines the amount of chloride ions passing the section of a 4 in concrete core that is subjected to two solutions on both sides $(\mathrm{NaOH} 0.3 \mathrm{M})$ and $(3 \% \mathrm{NaCl})$ by applying $\mathrm{DC}$ with a $60 \mathrm{~V}$ power source to induce ionic movement in the concrete core. The general assumption is that the higher the charge passed through the concrete core, the higher the permeability rate of concrete.

\subsection{Rapid Chloride Permeability Test (RCPT)}

RCPT results for that samples have different mass percentages of JORPHOS in the mix. Table 3 indicates the charge passed coulombs in core sample after $6 \mathrm{~h}$.

Table 3. Charge passed the core sample after $6 \mathrm{~h}$

\begin{tabular}{lllll}
\hline \multirow{2}{*}{ Sample Number } & \multicolumn{4}{l}{ JORPHOS to Cement mass percentage ratio in the mix } \\
\cline { 2 - 5 } & $0 \%$ & $4 \%$ & $8 \%$ & $12 \%$ \\
\hline 1st & $1690.2 \mathrm{C}$ & $681.2 \mathrm{C}$ & $312.5 \mathrm{C}$ & $126.4 \mathrm{C}$ \\
2nd & $1543.5 \mathrm{C}$ & $731.8 \mathrm{C}$ & $283.4 \mathrm{C}$ & $133.9 \mathrm{C}$ \\
3rd & $1764.1 \mathrm{C}$ & $722.7 \mathrm{C}$ & $207.5 \mathrm{C}$ & $128.7 \mathrm{C}$ \\
4th & $1708.4 \mathrm{C}$ & $715.0 \mathrm{C}$ & $221.6 \mathrm{C}$ & $133.1 \mathrm{C}$ \\
5th & $1793.3 \mathrm{C}$ & $620.6 \mathrm{C}$ & $308.1 \mathrm{C}$ & $125.2 \mathrm{C}$ \\
6th & $1805.7 \mathrm{C}$ & $554.4 \mathrm{C}$ & $255.9 \mathrm{C}$ & $136.4 \mathrm{C}$ \\
7th & $1844.5 \mathrm{C}$ & $497.5 \mathrm{C}$ & $216.7 \mathrm{C}$ & $122.4 \mathrm{C}$ \\
8th & $1674.3 \mathrm{C}$ & $656.8 \mathrm{C}$ & $311.1 \mathrm{C}$ & $130.7 \mathrm{C}$ \\
Avg. & $1728 \mathrm{C}$ & $647.5 \mathrm{C}$ & $264.6 \mathrm{C}$ & $129.6 \mathrm{C}$ \\
\hline
\end{tabular}


Figure 3 shows the relationship between charges passing in coulombs and the percentages of JORPHOS in the concrete mixture. The graph shows that as the percentage of JORPHOS increases, the charge passing in coulombs decreases with the exponential equation (1);where $\mathrm{R}^{2}$ is equal to 0.9951 correlation coefficient:

$$
\mathrm{y}=1623.7 \mathrm{e}^{-21.66 \mathrm{x}}
$$

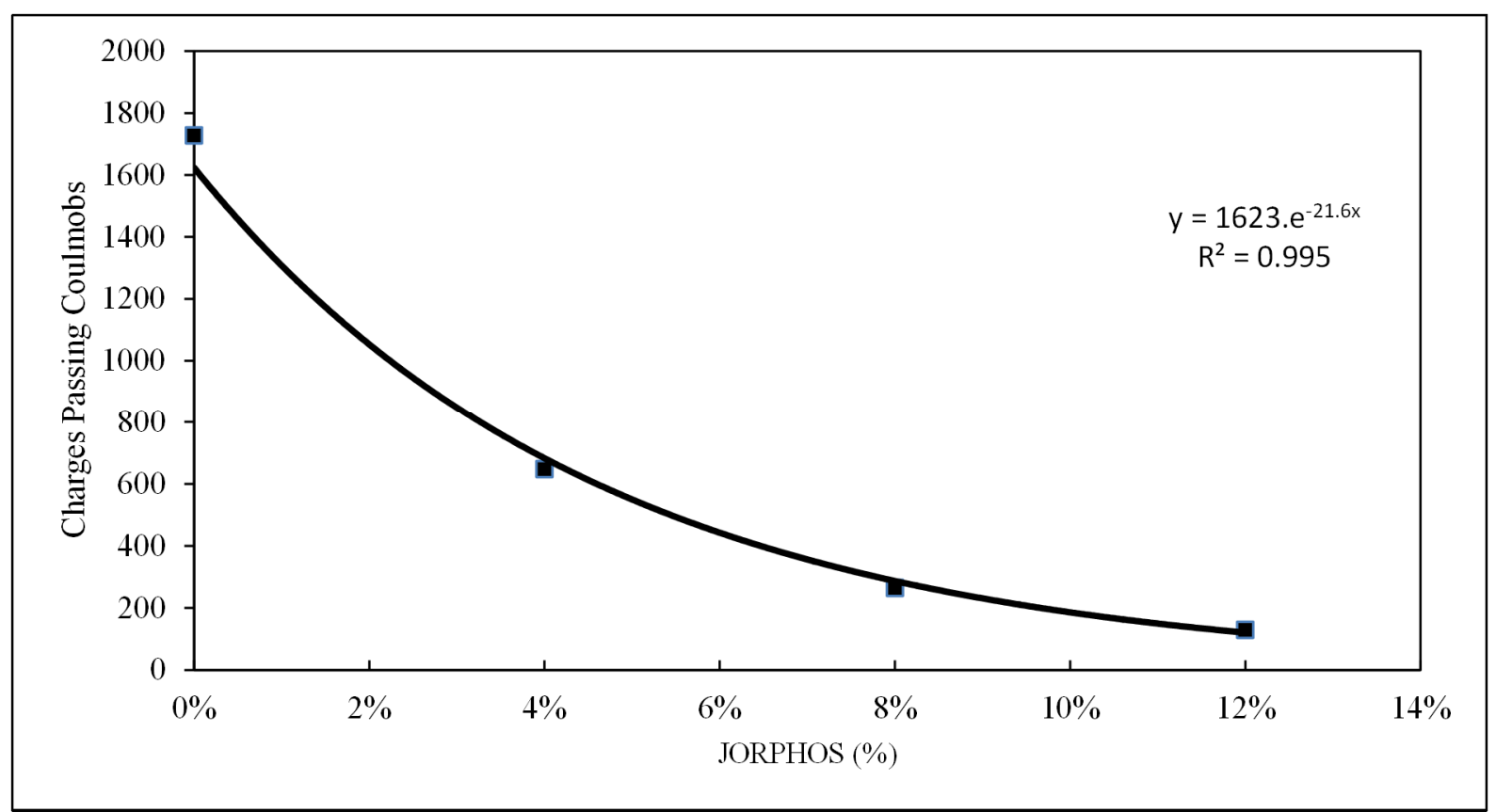

Figure 3. Average Test Results Chart of percentage of JORPHOS vs. Charges passed.

\section{Discussion and Conclusion}

From the Preceding results and according to the rating of the RCPT as shown in Table 4. Chloride Permeability of the $0 \%$ mix is low. Chloride Permeability of the $4 \%$ mix is very low. Chloride Permeability of the $8 \%$ mix is very low. Chloride Permeability of the $12 \%$ mix is very low. The $12 \%$ mix is the one with the lowest permeability to chloride. It must be taken into account that the RCPT does not measure the chloride ions alone but it is a measure of all the ions moving in the circuit and logged by the data logger.

Table 4. Rating of Chloride Permeability of Concrete According to the RCPT

\begin{tabular}{lcc}
\hline Chloride Permeability & Charge Passing Coulombs & Typical Concrete Type \\
\hline High & $>4000$ & High W/C ratio $(>0.6)$ Conventional PC Concrete \\
Moderate & 2000 to 4000 & High W/C ratio $(0.4$ to 0.5$)$ Conventional PC Concrete \\
Low & 1000 to 2000 & Low W/C ratio $(<0.4)$ Conventional PC Concrete \\
Very Low & 100 to 1000 & Latex-Modified Concrete \\
& & Internally Sealed Concrete \\
Negligible & $<100$ & Polymer-impregnated concrete. \\
& & Polymer Concrete \\
\hline
\end{tabular}

This research determined the ratio of JORPHOS that best resists chloride penetration $(0 \%, 4 \%, 8 \%$, and $12 \%)$ to reduce the effects of steel corrosion in reinforced concrete structures. Figure 3 shows the charge (coulombs) passing the cross section of the core is inversely proportional to the ratio of the JORPHOS in the mix. Therefore, the following conclusion can be drawn: the percentage of JORPHOS is inversely proportional to chloride permeability and the $12 \%$ mix is the best mix in this experiment. It is highly recommended for future researches to 
use ratios of JORPHOS greater than $12 \%$ to estimate the best proportion to be used to avoid chloride penetration. The higher the JORPHOS ratio, the lower the chloride penetration into concrete. This behavior (i.e. the relationship) between the ratio of JORPHOS and the charge passing is a result of the following factors:

- The $\mathrm{PO}_{4}^{-3}$ is a strong negative ion, which leads to a repulsion with the $\mathrm{Cl}$;

- The small grain size of the JORPHOS particles forms a filling material that prevents the ions from moving in the small pores or cracks of the concrete;

- $\quad$ The correlation coefficient is $99.15 \%$.

\section{References}

Alexander, M. G., Santhanam, M., \& Ballim, Y. (2010). Durability design and specification for concrete structures-the way forward. International Journal of Advances in Engineering Sciences and Applied Mathematics, 2(3), 95-105.

Brian, B. H., \& Alan, C. I. (1987). Corrosion of Steel in Concrete Made With Slag Cement. Materials Journal, 84(6). http://dx.doi.org/10.14359/2470

Concrete, C., \& Australia, A. (2009). Chloride resistance of concrete. Sydney: Cement Concrete \& Aggregate Australia.

Dhir, R. K., Jones, M. R., \& McCarthy, M. J. (online 12 February 1999). Binder content influences on chloride ingress in concrete. Cement and Concrete Research, 26(12), 5. http://dx.doi.org/10.1016/S0008-8846 (96)00179-2

Gjørv, O. E., \& Vennesland, Ø. (1979). Diffusion of chloride ions from seawater into concrete. Cement and Concrete Research, 9(2), 229-238. http://dx.doi.org/10.1016/0008-8846(79)90029-2

Gu, P., Beaudoin, J., Zhang, M.-H., \& Malhotra, V. (2000). Performance of reinforcing steel in concrete containing silica fume and blast-furnace slag ponded with sodium-chloride solution. ACI Materials Journal, 97(3).

Guirguis, S., Cement, \& Australia, C. A. O. (1989). Durable Concrete Structures: Cement and Concrete Association of Australia.

Jaegermann, C. (1990). Effect of water-cement ratio and curing on chloride penetration into concrete exposed to Mediterranean sea climate. ACI Materials Journal, 87(4).

Jensen, O. M., Hansen, P. F., Coats, A. M., \& Glasser, F. P. (1999). Chloride ingress in cement paste and mortar. Cement and Concrete Research, 29(9), 1497-1504. http://dx.doi.org/10.1016/S0008-8846(99)00131-3

Mehta, P. K. (1988). Durability of Concrete Exposed to Marine Environment-A Fresh Look. Special Publication, 109. http://dx.doi.org/10.14359/1899

Sandberg, P., Tang, L., \& Andersen, A. (1998). Recurrent studies of chloride ingress in uncracked marine concrete at various exposure times and elevations. Cement and Concrete Research, 28(10), 1489-1503. http://dx.doi.org/10.1016/S0008-8846(98)00124-0

Stark, D. (1995). Long-Time Performance of Concrete in a Seawater Exposure.

Tarek Uddin Mohammed, H. H., \& Toru, Y. (2004). Concrete after 30 Years of Exposure-Part II: Chloride Ingress and Corrosion of Steel Bars. Materials Journal, 101(1). http://dx.doi.org/10.14359/12983

\section{Copyrights}

Copyright for this article is retained by the author(s), with first publication rights granted to the journal.

This is an open-access article distributed under the terms and conditions of the Creative Commons Attribution license (http://creativecommons.org/licenses/by/3.0/). 